\title{
Why do Arab States Lag the World in Gender Equality?
}

\section{Citation}

Norris, Pippa. 2009. Why do Arab states lag the world in gender equality? HKS Faculty Research Working Paper Series RWP09-020, John F. Kennedy School of Government, Harvard University.

\section{Published Version}

http://web.hks.harvard.edu/publications/workingpapers/citation.aspx?Publd=6698

\section{Permanent link}

http://nrs.harvard.edu/urn-3:HUL.InstRepos:4415905

\section{Terms of Use}

This article was downloaded from Harvard University's DASH repository, and is made available under the terms and conditions applicable to Other Posted Material, as set forth at http:// nrs.harvard.edu/urn-3:HUL.InstRepos:dash.current.terms-of-use\#LAA

\section{Share Your Story}

The Harvard community has made this article openly available.

Please share how this access benefits you. Submit a story.

\section{Accessibility}


善 HARVARD Kennedy School

\author{
Faculty Research Working Papers Series
}

Why do Arab States Lag the World in Gender

Equality?

Pippa Norris

John F. Kennedy School of Government - Harvard University

July 2009

RWP09-020

The views expressed in the HKS Faculty Research Working Paper Series are those of the author(s) and do not necessarily reflect those of the John F. Kennedy School of Government or of Harvard University. Faculty Research Working Papers have not undergone formal review and approval. Such papers are included in this series to elicit feedback and to encourage debate on important public policy challenges. Copyright belongs to the author(s). Papers may be downloaded for personal use only. 


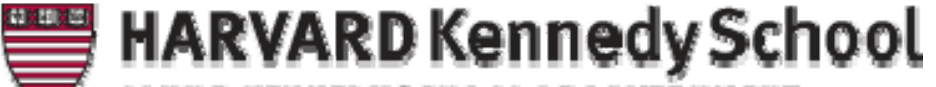 IOHN F. KENGEDY SCHOOL OFGOVERNM ENT}

\section{Why do Arab states lag the world in gender equality?}

\begin{tabular}{c} 
Pippa Norris \\
\hline Pippa Norris \\
McGuire Lecturer in Comparative Politics \\
John F. Kennedy School of Government \\
Harvard University \\
Cambridge, MA 02138 \\
Pippa Norris@Harvard.edu \\
www.pippanorris.com \\
\hline
\end{tabular}

Synopsis:

Why do Arab states lag behind the rest of the world in gender equality? Part I develops the theoretical debate. It first describes the 'petroleum patriarchy' thesis, presented in Michael Ross's "Oil, Islam and Women" (2008), which claims that the structure of oil-rich economies directly limit the role of women in the paid workforce and thus also (indirectly) restrict women's representation in parliament. As an alternative, it presents a cultural theories suggesting that religious traditions shape attitudes towards gender equality, and in turn these egalitarian attitudes influence the supply and demand process of political recruitment. Part II outlines the multilevel models, survey data and research design used to test the empirical evidence for these theories. Part III compares the impact of oil rents and religious traditions on egalitarian attitudes. Part IV then analyzes the impact of oil rents and cultural attitudes on the proportion of women in legislative and ministerial office. The conclusion summarizes the main findings and considers their implications.

Keywords: Gender equality, women's representation, cultural values, religion

Total words: 7,180

Draft: 7/6/2009 11:53 AM 
Achieving gender equality is a challenge for all states - but particularly for those in the Middle East. The Arab Human Development Report (UNDP 2006) highlights the multiple ways that gender equality continues to lag behind in the region when compared with the rest of the world. Some of the most difficult challenges concern elected office; women are roughly one in ten of the members of Arab parliaments (9.7\%), roughly half the world average (18.4\%). (IPU 2009) This pattern persists although some significant breakthroughs have occurred in particular states, notably the adoption and implementation of reserved seats in Morocco and candidate gender quotas in Iraq (Norris 2007). But the problem is not simply the lack of women's voices in the highest echelons of power. Most governments in the Middle East have now formally endorsed, with reservations, the Convention on the Elimination of All Forms of Discrimination against Women (CEDAW), pledging to establish women's rights. ${ }^{1}$ Yet the Arab Human Development Report documents that the region has some of the high rates of female illiteracy, and the lowest rate of female labor force participation, in the world. Women in the region encounter serious problems of basic health care, educational access, and income poverty, as well as suffering from exposure to violence, limited legal rights, and lack of access to justice. These conditions are compounded by problems of social exclusion, the curtailment of fundamental freedoms, and lack of democracy.

\section{I: Petroleum patriarchy or religious traditions?}

Why do Arab states lag behind the rest of the world in gender equality? Alternative explanations are offered by social structural and cultural accounts. These can each be regarded as rival theories, or else as complimentary parts of the same puzzle, for a more holistic understanding.

The traditional sociological perspective, which was perhaps the mainstream view during the 1960 s and 1970s, emphasizes that women's mass mobilization in politics, and their recruitment to leadership positions in the public sphere, have been hindered by structure of society, notably the traditional roles of men and women in the workforce, home and family. For example, an early classic study of engagement in American election campaigns by Kristi Andersen (1975) emphasized that the narrowing of the gender gap in mass participation during the post-war decades could be attributed to the entry of more women into the U.S. workforce. This viewpoint has becomes less common although it has not died away; contemporary studies continue to emphasize residual gender gaps in men and women's lives, whether in literacy, educational qualifications, family responsibilities, or work-based professional networks. All of these factors are regarded as limiting the resources, experience, and capacities which women bring both to civic engagement at mass level (Schlozman 1999), and well as to 
the pursuit of elected and appointed office for legislative, executive and judicial elites (Iversen and Rosenbluth 2008). In terms of public policies, the structural thesis suggests that more women will eventually be mobilized into mass politics, as well as being poised as eligible candidates on the first rungs of the ladder to enter political careers, as more women gradually move into the paid labor force in rising numbers, especially entering relevant occupations with higher status, relevant skills, and organizational networks in management and the professions.

This perspective was perhaps most popular during the 1960s and 1970s. During this era, in advanced industrialized economies more women were surging into higher education and the paid workforce, especially well-paid and high-status positions, and organizing to demand equality in the public sphere. The argument has come under increasing challenge in more recent decades, however, not least by the simple observation that millions of women have now entered higher education and the paid workforce in these economies, including United States and Japan, gradually rising in management and the professions. The ABA (2006) reports, for example, that today about half of the entrants to American law schools are women. Women constitute the majority of the U.S. college population. Yet countries such as the US and Japan continues to lag far behind the world average in the proportion of women in elected office, with the U.S. Congress currently ranked $72^{\text {nd }}$ and Japan Diet $105^{\text {th }}$ worldwide (IPU 2009). By contrast, far more women are members of parliament in some poorer developing societies, notably the well-known cases of Rwanda (ranked Number 1 ) and Cuba $\left(4^{\text {th }}\right)$, as well as in emerging economies, such as South Africa $\left(3^{\text {rd }}\right)$.

Structural arguments have also become increasingly less common in popular commentary due in part to their conservative policy implications; the idea of incremental social evolution in men and women's lives over successive generations has proved less attractive politically than 'fast track' institutional solutions, including gender quotas, which promise to dramatically and quickly transform women's representation over just a few successive elections (Dahlerup 2006; Krook 2009).

\section{Petroleum patriarchy?}

In a novel twist to an old argument, however, Michael Ross (2008) has recently breathed new life into the old structural thesis with the claim that the well-known 'resource curse', particularly the extraction and production of oil and gas, plays an important role in economic and political dimensions of gender equality. In "Oil, Islam and Women" (2008), Michael Ross builds on this catalogue of social ills by suggesting that petroleum also damages equality between men and women, both directly as well as indirectly. In particular, Ross's argument makes two core claims. 
First, he suggests that the structure of an economy which is heavily dependent upon oil and gas resources is directly responsible for the inequality of men and women's participation in the paid labor force. Manual jobs in the mining, extraction, refining and production of mineral resources are heavily male dominated, in contrast to service-sector economies.

Secondly, lower female labor force participation, he reasons, limits female opportunities to run for elected office. Labor force participation, he suggests, affect women's identities and perceptions, as well as their engagement in formal and informal networks, and the incentives for governments to take their interests into account. All these factors, Ross believes, should enhance women's political influence and thus more women in the workforce should facilitate their representation in elected and appointed office. The resource curse (petroleum) is thereby seen to indirectly reinforce patriarchal states.

To support these twin claims, econometric evidence is drawn from macro-level cross-national and time-series data. The key independent variable - the value of oil and gas production - is operationalized as oil and gas rents per capita. This represents the total annual value of a country's oil and gas production, minus the extraction costs in each country, divided by its population to normalize the value of the rents, measured from 1960 to 2002 in constant 2000 US dollars. The dependent variables for the econometric models are aggregate-level indicators of women's status, including the proportion of women in the paid labor force, and the fraction of parliamentary seats and ministerial positions held by women in 2002. Controls include levels of democracy and economic development, and the Muslim fraction of each country's population. The study also contrasts illustrative case studies of women's status in North African states with poor mineral resources, including Tunisia and Morocco, compared with their position in oil-rich Algeria. Ross concludes: "The extraction of oil and gas tends to reduce the role of women in the work force, and the likelihood that they will accumulate political influence..... In short, petroleum perpetuates patriarchy." (p120)

[Figure 1 about here]

\section{Or religious traditions?}

Yet the evidence concerning the Ross thesis is subject to a number of criticisms (see Kang 2009, Norris 2009, Charrad 2009) and an alternative explanation lies in the role of culture in determining gender equality in Arab states. A series of studies developed the basis of the analytical model set out in Figure 1 (Inglehart and Norris 2003; Norris and Inglehart 2003; Norris and Inglehart 2004). This theorizes that long-standing religious traditions in each society have a deep and enduring impact upon contemporary social values and moral attitudes, including support for gender equality in politics, as well 
as shaping broader attitudes towards sexual liberalization. In turn, the diffusion of more egalitarian attitudes in society facilitates the recruitment of more women to elected and appointed office, both by encouraging more women to come forward to pursue political careers (on the supply-side) as well as by shaping the attitudes of gate-keeping selectors and, ultimately, the broader electorate (on the demandside) (Norris and Lovenduski 1995). Culture does not act alone; the recruitment process is also conditioned by the institutional context, set by the electoral system and the use of any positive action strategies (Norris 2004). In particular, to explain the lack of female representation in the Arab states, the model suggests that any explanation needed to take account of a substantial gulf separating the more conservative and traditional attitudes towards the role of women in the public sphere which are commonly found in many Muslim-majority societies and the more egalitarian values which are far more pervasive among Western nations (Norris and Inglehart 2004).

\section{II: Data, evidence and multilevel models}

So does women's labour force participation and petroleum production matter for women in elected office - or are enduring religious traditions at the heart of any gender gap in oil rich states? To compare these alternative factors, and to reexamine and update the evidence, this study can examine data drawn from all five wave of the World Values Survey. In the first step, following the logic of the Norris and Inglehart thesis, this study first compares the relative impact of religious traditions and oil rents on attitudes towards gender equality. In the second step, it then examines the relative influence of egalitarian cultures and oil rents on the election of women to office.

The empirical evidence used in this study draws upon the World Values Surveys/European Values Surveys (WVS/EVS), pooled across all five-waves conducted from 1981-2007. This project has conducted representative national surveys of the basic values and beliefs of the publics in more than 90 independent countries, containing over 88 of the world's population and covering all six inhabited continents. The project builds on the European Values Survey, first carried out in 22 countries in 1981. A second wave of surveys was completed in 43 countries 1990-1991. A third wave was carried out in 55 nations in 1995-1996, and a fourth wave, in 59 countries, took place in 1999-2001. The fifth wave covering 55 countries was conducted in 2005-2007. ${ }^{2}$

Most importantly for our purposes, the survey includes systematic data on public opinion in twenty diverse Islamic states containing Muslim-plurality populations, listed in Table 1, providing some of the broadest global comparison available from any existing representative social survey. Societies in the World Values Survey are classified by their predominant religion, based on estimates of the religious 
population contained in the CIA World Factbook. Islamic nations are defined as those where the Muslim population is the largest plurality (although societies may, and often do, also contain substantial minorities of other faiths). It is important to compare a wide variety of societies to examine the variety of attitudes and values found among Muslim nations around the globe (Moaddel 2007). The World Values Survey includes Arab states, both majority Sunni (such as Jordan, Algeria, Morocco, and Egypt) and majority Shi'a (such as Iran and Iraq), as well as countries in Asia (Azerbaijan, Kyrgystan, Pakistan, Bangladesh, Malaysia), Central Europe (Bosnia Herzegovina, Albania), and in Sub-Saharan Africa (Mali, Nigeria, Burkina Faso). The survey also covers states that have adopted Islam as the foundation of political institutions (such as Saudi Arabia and Pakistan), societies where Islam is the official or established state religion (including Egypt, Bangladesh, and Malaysia), and secular states where the constitution is neutral towards religion (such as Turkey, Azerbaijan, Indonesia). The surveys contain eight of the ten most populous Muslim nations around the globe, including the top three, Indonesia, Pakistan and Bangladesh. The WVS/EVS surveys also covers societies with all levels of economic and human development, including many affluent Western countries, such as the U.S., Japan and Switzerland, with per capita annual incomes over $\$ 40,000$; together with middle-level Muslim countries including Malaysia, Turkey and Saudi Arabia, as well as poorer Muslim societies, such as Bangladesh, Mali and Burkina Faso, with per capita annual incomes of $\$ 500$ or less. In terms of regimes, Saudi Arabia is an absolute monarchy, which Freedom House (2009) classifies as one of the world's most restrictive states in respect for civil liberties and political rights, but the World Values survey also monitored public opinion in the democratic states of Mali and Indonesia, as well as the secular state of Turkey. ${ }^{3}$

[Table 1 about here]

A series of items were selected from the WVS/EVS survey to monitor cultural values towards gender and sexuality, and their dimensions were examined using factor analysis. The results presented in Table 2 show that the items monitoring tolerance of homosexuality, abortion and divorce formed one consistent dimension, representing positive orientations towards issues of sexual liberalization. The items concerning gender equality tapped into approval of traditional or egalitarian roles for men and women in the workforce, elected office and university education, forming another consistent scale, as used in an earlier detailed study (Inglehart and Norris 2003). The two separate dimensions were each summed and standardized into 100-point scales, for ease of comparison, with the full details listed in the Technical Appendix. It should be noted that not all items were available across all waves and 
countries of the survey, reducing the total number of countries for the multilevel analysis to almost three-dozen.

\section{[Table 2 about here]}

To replicate the petroleum patriarchy thesis, the analysis includes the measure of Oil Rents per Capita, which Ross argues is the most appropriate indicator of oil and gas production. The total value of mineral production might be a better indicator of the 'resource curse' thesis, or the proportion of the population employed in this sector of the economy, for the reasons discussed earlier, but to replicate Ross, it is important to retain his measure and data for Oil Rents. The Ross study also suggests the need to examine the impact of participation in the paid labor force, since this could potentially affect women and men's cultural attitudes, as well as providing the organizational networks and the resources which facilitate political engagement. Accordingly, paid work force participation (either full or part time) is included in the models.

The first step is to test the relative importance of religious traditions or oil rents on support for either traditional or liberal values towards gender equality and sexual liberalization. Based on cultural theories (Norris and Inglehart 2004), this study predicts that religious traditions will play a central role in shaping attitudes at two levels. In particular, this study predicts that (H\#1) individual Muslim religious identities will strengthen traditional values towards gender equality and sexual liberalization. For the same reasons, it is expected that $(\mathrm{H} \# 2)$ the strength of individual religiosity will also bolster traditional values. The strength of religiosity is monitored here by the importance of religion, as measure closely associated with religious practices and behavior (Norris and Inglehart 2004). It is also predicted that there will be a more diffuse cultural effect, so that $(\mathrm{H \# 3}$ living in Islamic societies will also strengthen traditional values. In this regard, we expect individuals who do not subscribe to the Muslim religious identity or faith, such as Christians in Iraq or Hindus living in Pakistan, will still be influenced by the predominant norms and moral attitudes within Muslim communities. To compare cultural explanations against the resource curse thesis, this study also tests the rival prediction $(\mathrm{H \# 4)}$ that societies with high oil rents will display more traditional values. The models control for the standard demographic and social factors commonly associated with cultural attitudes and values, measured at individual level, namely age, gender, household income, education, labor force participation, marital status and religiosity, as well as controlling for per capita GDP, and the location of countries in the Middle East region, at national level. The use of the two indicators of cultural attitudes -- towards gender equality and sexual liberalization - provides a cross-check on the robustness of the results. 
To operationalize these factors, the key models involve measurement at two distinct levels. A representative sample of individual respondents (level 1) is nested within national-level contexts (level 2). The WVS/EVS was conducted among a representative random sample of the adult population within each country. The use of Hierarchical Linear Models, in particular multilevel regression analysis, is the most appropriate technique for comparing the impact of societal-level and individual-level factors simultaneously. The models in this study use restricted maximum likelihood techniques (REML) to estimate direct and cross-level effects for hierarchical data. Individual respondents are thus grouped into countries. Each country has a different set of parameters for the random factors, allowing intercepts and slopes to vary by nation (Raudenbush and Bryk 2002; Gelman and Hill 2007; Bickel 2007). In hierarchical linear models, as is customary, all independent variables were centered, by subtracting the grand mean (which becomes zero). The standardized independent variables all have a standard deviation of 1.0. This process also helps to guard against problems of collinearity in the independent variables in the OLS models. The independent variables were treated as fixed components, reflecting the weighted average for the slope across all groups, while nation was treated as a random component, capturing the country variability in the slope. The strength of the beta coefficients (slopes) can be interpreted intuitively as how much change in the dependent variable is generated by a one-percent change in each independent variable. The multilevel regression models used in this study usually generate small differences in the size of the slope coefficient (b) compared with the results of OLS models, but the average standard errors for level 2 variables tend to be slightly larger. The process is thus more rigorous and conservative than OLS, avoiding Type I errors (false positives, concluding that a statistically-significant difference exists when, in truth, there is no statistical difference). In the REML model, by contrast, Schwarz's Bayesian Criterion (BIC) is used, where the model with the lower value is the best fitting.

Level 1 in our core models includes individual-level Muslim religious identities, and the strength of religiosity, along with several other standard controls, described in the Technical Appendix, including male gender (0/1), household income using a 10-point scale, age (in years), an education scale, marital status, and labor force participation. Level 2 includes national-level variables, including the classification of Islamic or non-Islamic societies, based on the plurality faith in each country's population. In addition, we also control for the regional location, classified as in the Middle East or elsewhere in the world, to test whether global areas differ. This study also models the effects of Oil Rents Per Capita, to test the alternative resource curse thesis. 


\section{III: What explains cultural values towards gender equality: religion or oil?}

If we first look at the descriptive statistics, Figure 2 shows the distribution of Islamic and Western societies on the gender equality and the sexual liberalization 100-point scales, without any controls. The scatter-plot illustrates the strong clustering of cultures on these dimensions, with the Islamic societies concentrated in the left-bottom quadrant, displaying the most traditional attitudes. Saudi Arabia, Jordan and Egypt prove the most conservative on these indicators, but other predominately Muslim states from Asia and Africa are relatively closely located. By contrast, the affluent post-industrial Western societies are all clustered in the right-hand-top quadrant, led by Sweden, representing the most egalitarian and liberal values. Interestingly the Islamic societies closest to this position (Bosnia-Herzegovina and Albania) are both in Europe.

[Table 2, Figures 2 and 3 about here]

If we dichotomize the measure of oil rents per capita to generate two categories, we can also look at attitudes among oil rich and oil poor types of economies, as well as comparing countries with predominant Islamic or non-Islamic religious traditions. Figure 3 shows the mean position of each types of society in terms of the support for gender equality and the sexual liberalization scales, again without any controls. It is immediately apparent that the most traditional attitudes towards gender equality values are found in the oil-rich Islamic states. But does an oil economy or religious culture matter most in this regard? The sharp contrast with the egalitarian attitudes expressed by non-Islamic cultures in oil rich states, generating a 25-point gap between these groups, suggests that the type of faith is more important than natural resources per se. There is a smaller 10-point gap in support for gender equality among Islamic and non-Islamic societies without substantial oil rents, although this pointed in the expected direction. To check whether these patterns were due to the selection of the particular questions used in constructing the gender equality scale, or whether the results were robust, similar comparisons can be made using the sexual liberalization scale. The results in Figure 3 provided even stronger indications that the type of oil-rich or poor society made no difference to these moral attitudes; by contrast people living in different religious cultures expressed sharply contrasting sexual values.

[Table 3 about here]

On the other hand, obviously many other factors could be driving these differences, beyond religious culture, such as levels of economic development. Table 3 presents the results of the multilevel regression models predicting cultural values, with the predictor variables, and the individual and 
societal-level controls. The models explaining both attitudes towards gender equality and towards liberal sexual morality show strikingly consistent relationships across nearly all variables, lending confidence to the robustness of the results. The most important findings concern the relative strength of the key predictor variables: individual Muslim identities, living in an Islamic society, and the strength of religiosity were all significantly associated with more traditional attitudes. The coefficient for oil rents per capita was also significant, but in an unexpectedly positive, not negative, direction. This is contrary to the Ross thesis, and requires further investigation. Labor force participation was significantly associated with more liberal attitudes, however. Most importantly, among all the predictor variables, living in a predominately Muslim society proved by far the strongest factor. The diffuse impact of religious traditions within each society on attitudes towards women thus outweighs individual religious identities and the strength of religiosity; what appears to matters is where you live more than your type of faith or your adherence to religious practices.

The remaining controls mostly behaved as expected, with support for gender equality and sexual liberalization values stronger among the younger generation, women, the more affluent and educated, those in employment and those who were not currently married. Once all these factors were entered into the models, the remaining national-level controls, including levels of economic development and the Middle East as a region, were not consistently significant. Overall the models indicate that the predominant or diffuse religious traditions in Muslim societies provides the strongest impact on attitudes towards the most appropriate role for women and men - as well as shaping broader moral values concerning issues of tolerance of homosexuality, divorce and abortion.

\section{IV: What explains women's representation in parliament: egalitarian attitudes or oil?}

Building upon these foundations, as a second step we can also compare the impact of religious cultures, egalitarian cultural values, and oil rents at societal level on women's representation in parliament. Figure 4 presents the simple descriptive statistics analyzing the proportion of women elected to the lower house of parliament as well as the proportion of women ministers in higher office in 2005. Comparisons can be drawn between Islamic and non-Islamic societies, as well as between oil rich and poor economies. The results in Figure 3 are similar to those observed earlier concerning attitudes towards gender equality; women are far more successful in gaining legislative and ministerial office power in non-Islamic societies, whether oil rich or oil poor. By contrast, women are usually less successful in Islamic societies, whether oil rich or poor. In short, the religious culture seems to stamp a strong imprint on opportunities for women's leadership, most plausibly by influencing attitudes among 
potential female candidates, as well as the decisions of the selectorates and gatekeepers to elected office, whereas the resource curse (oil rents) does not seem to matter.

[Figures 4 and 5 about here]

To examine this pattern in more detail, however, we can also see how particular countries are distributed, using the scatter-grams presented in Figure 5. The top graph illustrated the relationship between the proportion of women members in the lower house of parliament in 2005 and the mean support for egalitarian cultural attitudes across different societies. Societies are also classified by the type of Islamic or non-Islamic religious tradition. The results further confirm the significant positive correlation between egalitarian attitudes and women's election, as noted in 2000 (Inglehart and Norris 2003). This pattern is stronger in the non-Islamic societies $\left(R^{2}=.177\right)$, but which also exists to differentiate more or less traditional Islamic cultures $\left(R^{2}=.108\right)$. The correlation is not particularly strong, not surprisingly as many other institutional conditions also influence men and women's access to elected office, not least the type of electoral system and any affirmative action measures used in the recruitment process (Norris 2004; Krook 2009). In some cases, such as Rwanda, the proportion of women in office is ahead of public opinion (largely due to top-down positive action measures), while in a few other cases, such as the U.S. and France, this relationship was reversed (suggesting that public opinion among the electorate is less of a potential barrier than the practical obstacles, such as the need to gain party endorsements or campaign resources, facing women seeking elected office). Nevertheless the evidence presented here and elsewhere suggests that the predominant religious tradition in any society also matters, by influencing the supply and the demand for female recruitment.

To consider again the rival structural account, the bottom graph in Figure 5 compares women in elected office against the logged distribution of oil rents per capita. By contrast, there appears to be no significant correlation and countries are widely scattered across the graph; women are elected in relatively substantial numbers in societies as diverse as Iraq, Canada, Trinidad and Tobago (as well as Norway), despite relatively high oil rents per capita, whereas among the oil-poor nations, women do badly in elected office Jordan and Armenia as well as doing remarkably well in Sweden and Finland. Indeed the tight clustering of Scandinavian countries on the top graph in Figure 5, (with a shared egalitarian culture which favor equal opportunities for women), whereas the wide dispersion of Sweden and Norway on the bottom graph, summarizes the story presented here. 


\section{V: Conclusions and discussion}

Petroleum perpetuates patriarchy? Any observers looking at the limited rights which women face in some of the major oil-rich states, such as Saudi Arabia, Qatar and the United Arab Emirates, might easily be persuaded that there could indeed be a strong linkage. But a more detail analysis of the evidence suggests that structural accounts of gender inequality have always suffered from several major flaws, and the petroleum patriarchy thesis does not stand up to scrutiny. It seems more plausible to conclude that long-standing religious traditions leave an enduring mark on the norms and beliefs, the attitudes and values, which characterize different societies. These cultural values leave a deep imprint upon the way that men and women see the most appropriate division of labor for men and women in the home, family and public sphere - including the contemporary role of women in elected office. Thus Buddhist and Confucian, Catholic and Protestant, Hindu and Muslim societies each display certain distinctive ideas about gender and sexuality -and these values continue to leave an imprint on the lives of women and men, even when post-industrial societies become more secular in orientation. Active engagement in Protestantism has thus gradually dwindled and died out in Scandinavian countries (Norris and Inglehart 2004), including involvement in religious services and organizations, as well as adherence to the importance of religion in people's lives. Nevertheless the legacy of religious traditions continues to be evident in contemporary Scandinavian values.

The imprint of these religious traditions thus influences attitudes about whether women should play a leadership role in public life - and in turn, as illustrated in Figure 1, these attitudes facilitate or hinder the recruitment of women into elected and appointed office. Cultural barriers are not fixed in stone, as there is a wealth of evidence that values towards gender equality can and do gradually change on a generational basis, mainly in response to long-term processes of societal modernization. In the short term, as well, cultural barriers can also be overcome by the effective implementation of welldesigned institutional reforms, as exemplified most dramatically by the election of women through the use of reserved seats in Afghanistan and the use of candidate gender quotas in Iraq. Through these mechanisms, women have a voice in the future of their countries.

Therefore the research literature presents a wealth of evidence that the resource curse can probably be blamed for a multitude of ills. The heightened danger of state capture and rent-seeking by ruling elites generate poorer prospects for the transition from autocracy and the consolidation of stable democracies (Auty 1993; Ross 2001; Boix 2003; Jensen and Wantchekon 2004; Dunning 2008). Lootable mineral resources, in particular, are thought to make a country particularly vulnerable to civil war, 
insurgency, and rebellion (Collier and Sambanis 2005; Humphreys 2005; Snyder 2006; Ross 2004, 2006). But the resource curse, at least petroleum, does not appear to be a major factor at the heart of the problems facing the continuing gender disparities in elected office among Arab states. 
Table 1: Muslim countries contained in the World Values Surveys, 1981-2005

\begin{tabular}{|c|c|c|c|}
\hline & Country & $\%$ Muslims & Global region \\
\hline 1 & Iraq & 98.9 & Middle East \\
\hline 2 & Algeria & 98.0 & North Africa \\
\hline 3 & Iran & 97.7 & Middle East \\
\hline 4 & Saudi Arabia & 97.0 & Middle East \\
\hline 5 & Jordan & 96.9 & Middle East \\
\hline 6 & Egypt & 94.3 & North Africa \\
\hline 7 & Mali & 93.0 & West Africa \\
\hline 8 & Indonesia & 92.2 & South East Asia \\
\hline 9 & Azerbaijan & 91.0 & Central Europe \\
\hline 10 & Bangladesh & 88.7 & South Asia \\
\hline 11 & Turkey & 81.7 & Central Europe \\
\hline 12 & Kyrgyzstan & 74.3 & Central Asia \\
\hline 13 & Pakistan & 69.6 & South Asia \\
\hline 14 & Albania & 64.3 & Central Europe \\
\hline 15 & Morocco & 63.6 & North Africa \\
\hline 16 & Malaysia & 57.4 & South East Asia \\
\hline 17 & Burkina Faso & 53.3 & Sub-Saharan Africa \\
\hline 18 & Bosnia & 48.9 & Central Europe \\
\hline 19 & Tanzania & 40.1 & East Africa \\
\hline 20 & Nigeria & 28.1 & West Africa \\
\hline
\end{tabular}

Source: Pooled World Values Survey, 1981-2007 
Table 2: Dimensions of cultural value scales

\begin{tabular}{l|l|l|}
\hline & .753 & $\begin{array}{l}\text { Gender } \\
\text { equality } \\
\text { liberalization }\end{array}$ \\
\hline Justifiability abortion & .745 & .742 \\
Justifiability divorce & .702 & .719 \\
Justifiability homosexuality & .669 \\
\hline Men make better political leaders than women & & \\
University education more important for a boy & & 13.4 \\
Men should have more right to a job than women & 16.5 & \\
\hline
\end{tabular}

Notes: Individual-level Principal Component Factor Analysis was used to develop the scales with varimax rotation and Kaiser Normalization, excluding coefficients below 0.40 . See the technical appendix for the detailed survey items.

Source: Pooled World Values Survey, 1981-2007 
Table 3: Multilevel model predicting cultural values

\begin{tabular}{lrr}
\hline & Gender equality & Liberal sexual morality \\
\hline PREDICTOR VARIABLES & $-0.95 * * *$ & $-0.53 * * *$ \\
Muslim religious identity & $(.110)$ & $(.137)$ \\
& & $-20.93 *$ \\
Islamic society & $-16.97 * * *$ & $(1.06)$ \\
Strength of religiosity & $(6.00)$ & $-7.78 * * *$ \\
& $-1.81 * * *$ & $(.087)$ \\
Oil rents per capita & $(.090)$ & $1.74 * * *$ \\
& & $(205)$
\end{tabular}

\section{INDIVIDUAL-LEVEL CONTROLS}

Age (years)

Gender (male=1)

Household income 10-pt scale

Education 9-pt scale

Labor force participation

Marital status

$-1.26 * * *$

(.078)

$-3.81 * * *$

(.067)

$1.09 * * *$

(.073)

$2.94 * * *$

(.076)

$0.61 * * *$

(.070)

$-0.44 * *$

(.069)
$-2.12 * * *$

(.084)

$-2.18 * * *$

$1.14 * * *$

$3.00 * * *$

$1.37 * * *$

$-1.07 * * *$

(.076)

\section{NATIONAL-LEVEL CONTROLS}

Middle East

GDP per capita

Note: All independent variables were standardized using mean centering (z-scores). Models present the results of the REML multilevel regression models including the beta coefficient, (the standard error below in parenthesis), and the significance. The 100 point scales are constructed from the items listed in Table 2. P.*>.05

Source: Pooled World Values Survey 1981-2007. 
Figure 1: Theoretical model of how religious traditions shape women's representation

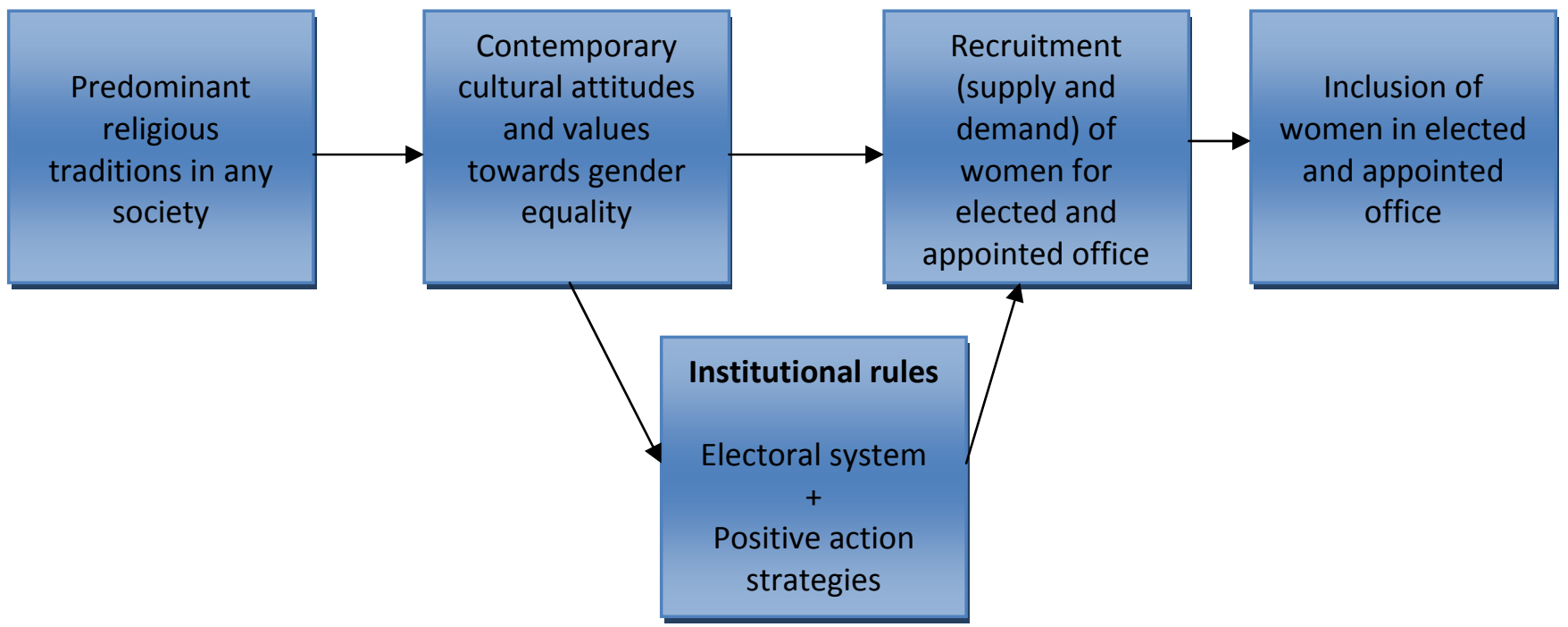


Figure 2: Sexual liberalization and gender equality values by type of society

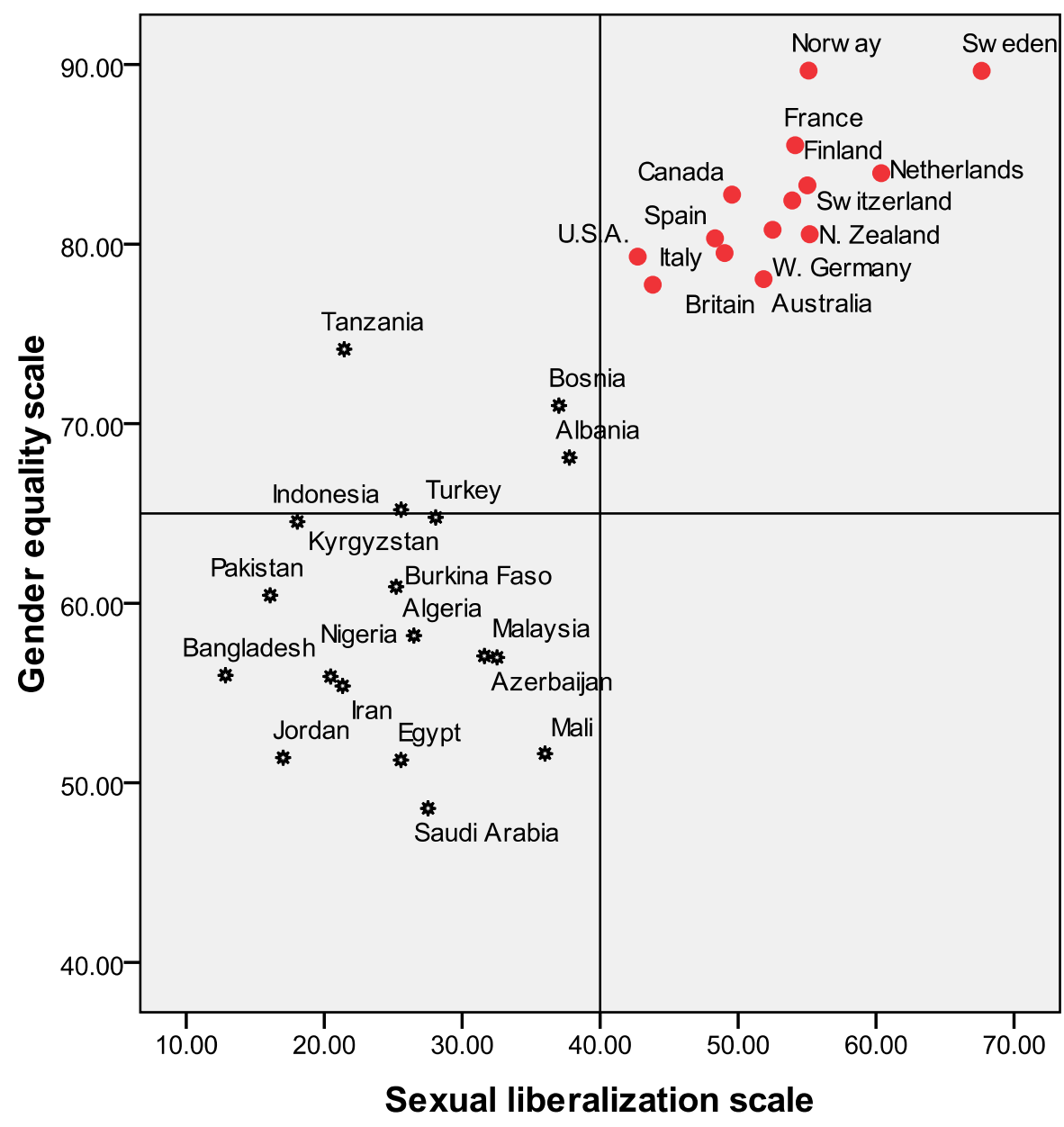

Type of society

Western society

* Islamic society

Note: For the two 100-point value scales, see the Technical Appendix.

Source: pooled World Values Survey 1981-2007. 
Figure 3: Support for gender equality and sexual liberalization

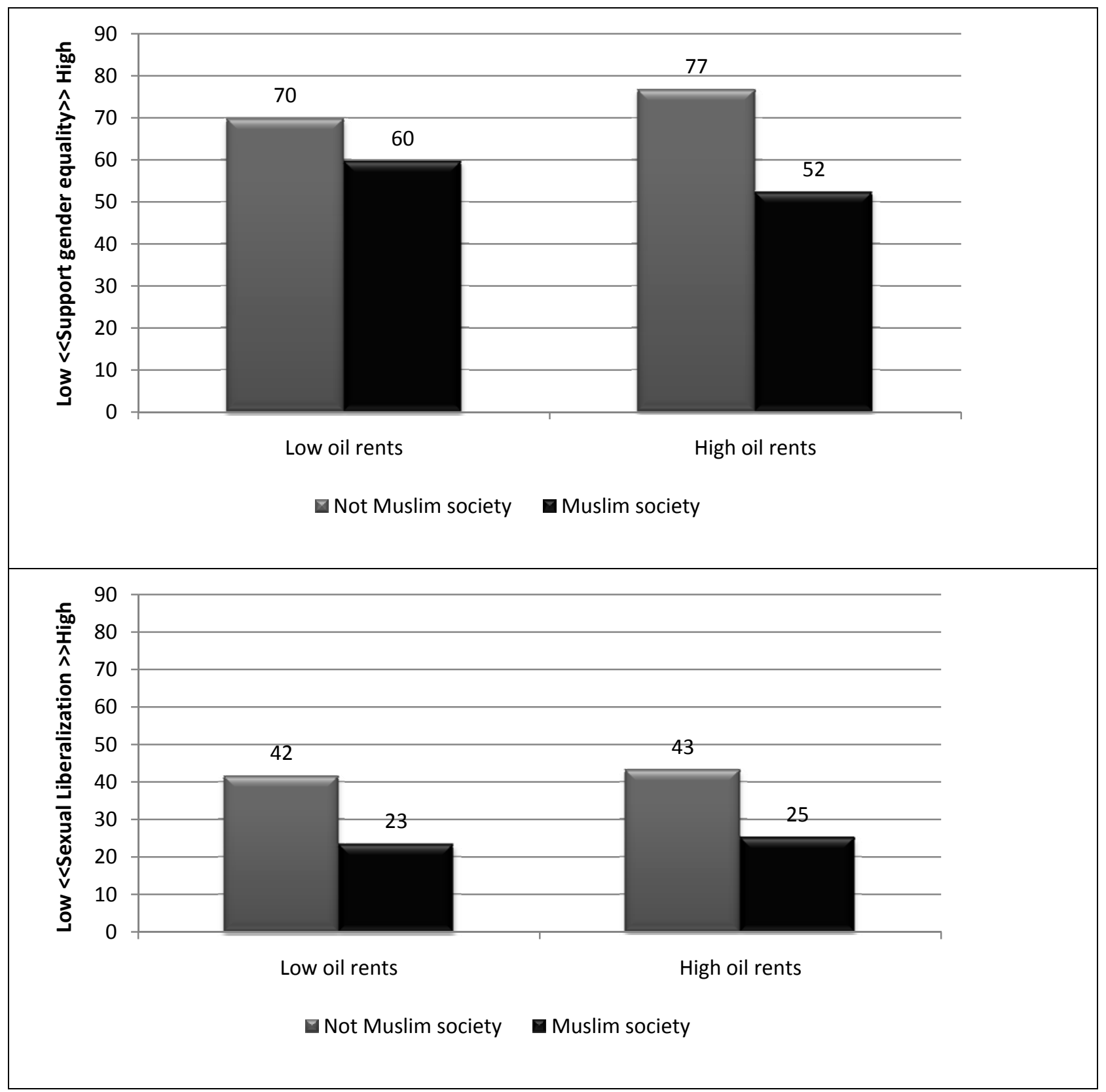

Note: For the two 100-point value scales, and the classification of societies, see the Technical Appendix. Source: pooled World Values Survey 1981-2007. 
Figure 4: Women in elected office, 2005

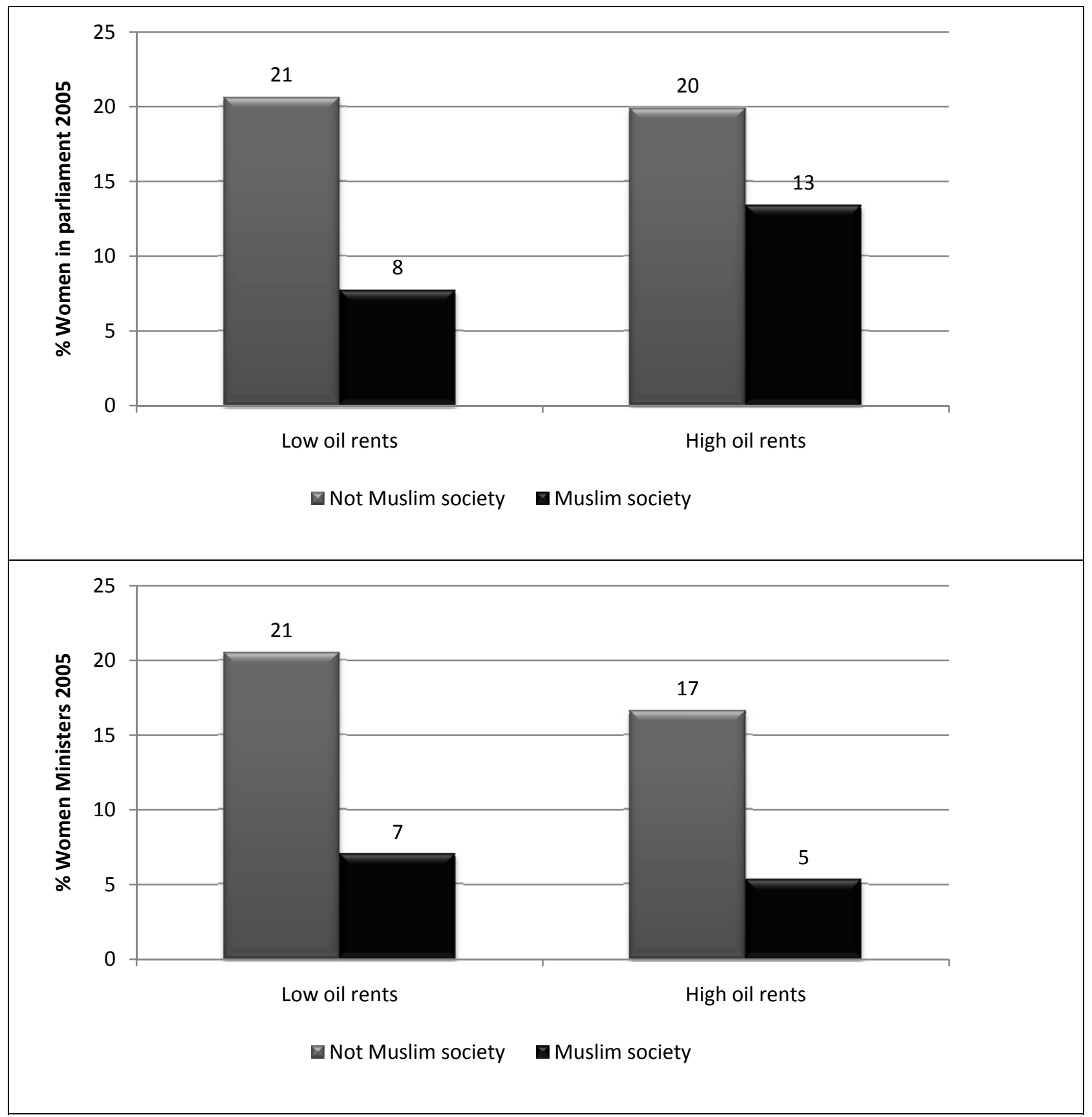

Source: The proportions of women in the lower house of parliament and in ministerial office (2005) are derived from the Inter-Parliamentary Union. www.IPU.org 
Figure 5: Cultural attitudes, oil, and the proportion of women in parliament, 2005

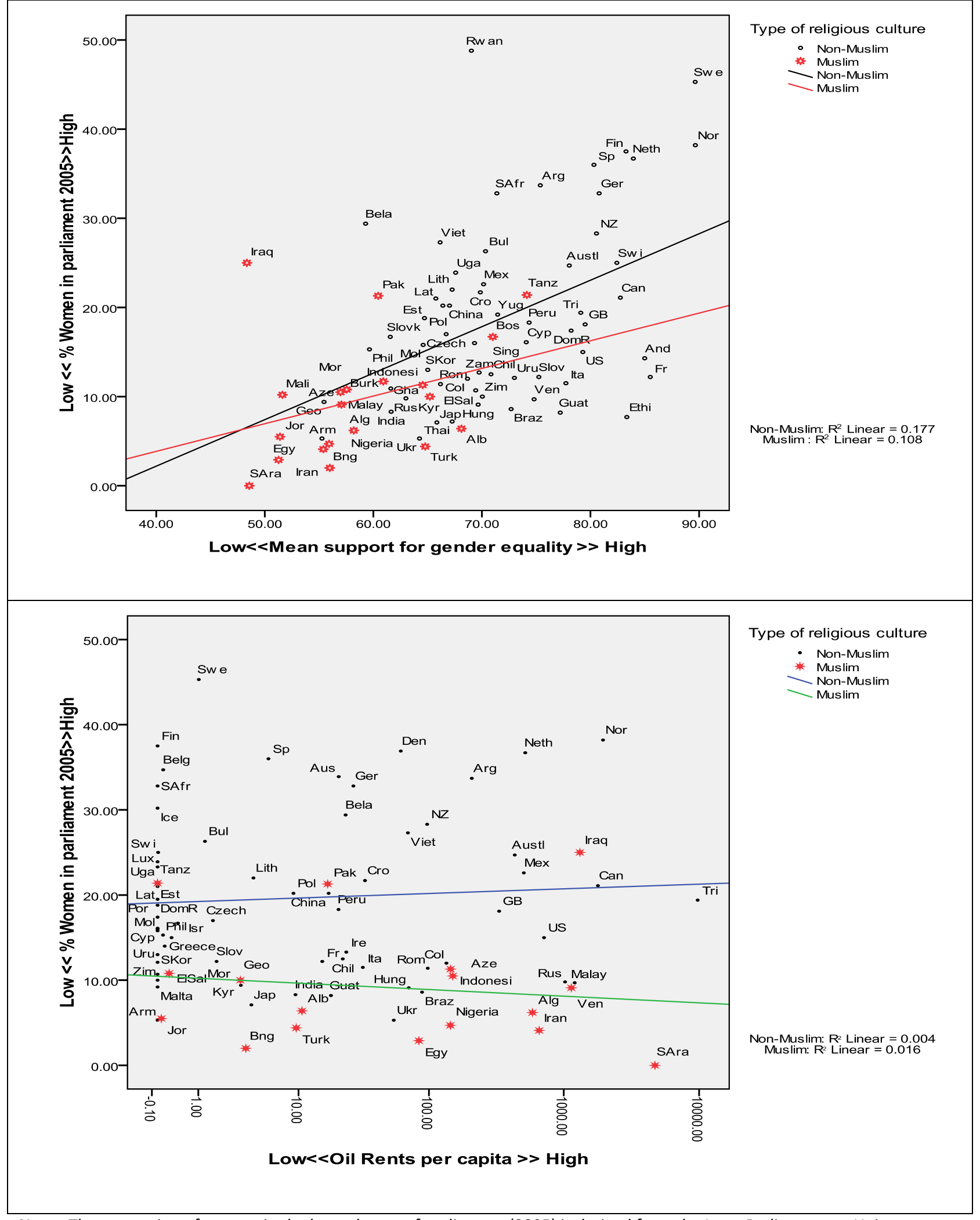

Note: The proportion of women in the lower house of parliament (2005) is derived from the Inter-Parliamentary Union. www.IPU.org. See the Appendix for the other measures. 
Technical Appendix A: Concepts and Measures

\begin{tabular}{|c|c|}
\hline Variable & Definitions, coding and sources \\
\hline Per Capita GDP & $\begin{array}{l}\text { Measured in constant international \$ in Purchasing Power Parity. Various years. } \\
\text { Source: The World Bank. World Development Indicators. }\end{array}$ \\
\hline Type of religion & $\begin{array}{l}\text { V184: “Do you belong to a religious denomination? [IF YES] Which one?" Coded: } \\
\text { No, not a member; Roman Catholic; Protestant; Orthodox (Russian/Greek/etc.); } \\
\text { Jewish; Muslim; Hindu; Buddhist; Other. Source: World Values Surveys. }\end{array}$ \\
\hline $\begin{array}{l}\text { Type of } \\
\text { predominant } \\
\text { religion in each } \\
\text { society }\end{array}$ & $\begin{array}{l}\text { The classification of the major religion (adhered to by the plurality groups in the } \\
\text { population) in all } 193 \text { states around the world is based on the CIA. The World } \\
\text { Factbook, 2009. (Washington, DC: Central Intelligence Agency). Source: } \\
\text { http://www.cia.gov/cia/publications/factbook }\end{array}$ \\
\hline Islamic societies & $\begin{array}{l}\text { Based on the societies with Muslim plurality populations, based on the above } \\
\text { source, as listed in Table } 1 \text {. It should be noted that throughout the paper the term } \\
\text { 'Islamic' is used to refer to Muslim-plurality societies, and it is not used to describe } \\
\text { the official religion or policies of the state, or the relation between religious and } \\
\text { political authorities. 'Muslim' refers to individuals who identify with the Muslim } \\
\text { faith. }\end{array}$ \\
\hline $\begin{array}{l}\text { Gender equality } \\
\text { scale }\end{array}$ & $\begin{array}{l}\text { The combined 100-pt gender equality scale is based on the following } 3 \text { items: } \\
\text { MENPOL Q118: "On the whole, men make better political leaders than women do." } \\
\text { (Agree coded low); MENJOBS Q78: "When jobs are scarce, men should have more } \\
\text { right to a job than women." (Agree coded low); BOYEDUC Q.119: "A university } \\
\text { education is more important for a boy than a girl." (Agree coded low). Source: } \\
\text { World Values Surveys. }\end{array}$ \\
\hline $\begin{array}{l}\text { Sexual } \\
\text { liberalization } \\
\text { value scale }\end{array}$ & $\begin{array}{l}\text { "Please tell me for each of the following statements whether you think it can } \\
\text { always be justified (10), never justified (1), or somewhere in-between, using this } \\
\text { card...Abortion, Homosexuality, Divorce". Source: World Values Surveys }\end{array}$ \\
\hline $\begin{array}{l}\text { Occupational } \\
\text { Class }\end{array}$ & $\begin{array}{l}\text { Coded for the respondent's occupation. "In which profession/occupation do you, } \\
\text { or did you, work?" The scale is coded into } 4 \text { categories: Professional/manager (1); } \\
\text { Other non-manual (2); Skilled non-manual (3); Unskilled Manual Worker (4). } \\
\text { Source: World Values Surveys }\end{array}$ \\
\hline Paid work status & $\begin{array}{l}\text { V220. "Are you employed now or not?" Coded fulltime, part-time or self-employed } \\
\text { (1), other (0). Source: World Values Surveys }\end{array}$ \\
\hline Education & $\begin{array}{l}\text { V217. "What is the highest educational level that you have ever attained?" Coded } \\
\text { on a 9-point scale from no formal education (1) to university level with degree (9). } \\
\text { Source: World Values Surveys }\end{array}$ \\
\hline \multirow[t]{2}{*}{ Age } & $\begin{array}{l}\text { Age coded in continuous years derived from date of birth. Source: World Values } \\
\text { Surveys. }\end{array}$ \\
\hline & Age groups: Younger (18-29), middle (30-49), and older (50+). \\
\hline Religiosity & V192 'How important is God in your life' 10-point scale \\
\hline
\end{tabular}




\begin{abstract}
Household Income V253 "On this card is a scale of incomes on which 1 indicates the "lowest income decile" and 10 the "highest income decile" in your country. We would like to know in what group your household is. Please, specify the appropriate number, counting all wages, salaries, pensions and other incomes that come in." (Code one number). Source: World Values Surveys

Education scale V238. "What is the highest educational level that you have attained?" [NOTE: if respondent indicates to be a student, code highest level s/he expects to complete]: (1) No formal education; (2) Incomplete primary school; (3) Complete primary school; (4) Incomplete secondary school: technical/vocational type; (5) Complete secondary school: technical/vocational type; (6) Incomplete secondary: universitypreparatory type; (7) Complete secondary: university-preparatory type; (8) Some university-level education, without degree; (9)University-level education, with degree. Source: World Values Surveys
\end{abstract}

\section{\% Women in parliament}

\% Women ministers

Oil rents per capita

Oil rent categories
Proportion of women in the lower house of the national parliament, latest election 2005. Source: Inter-Parliamentary Union.

Proportion of women ministers in the national cabinet, 2005. Source: InterParliamentary Union.

Oil and gas rents per capita, measured by the total value of production minus the extraction costs, normalized by the country's population. The data relates to the year closest to the WVS survey wave. Source: Michael Ross (2008).

'Low' and 'high' oil rent societies are classified for the countries contained in the WVS by dichotomizing the value of oil rents per capita (see above) around the mean.

Note: Full details of the World Values Survey codebooks and questionnaires can be found at www.worldvaluessurvey.com.

\title{
References
}

Abu-Lughod, Lila. Ed. 1998. Remaking women: feminism and modernity in the Middle East. Princeton: Princeton University Press.

American Bar Association. 2006. Charting our progress: the status of women in the profession today.

Chicago: ABA/Commission on Women in the Profession. http://www.abanet.org/women/reports.html

Andersen, Kristi. 1975. 'Working women and political participation, 1952-1972.' American Political Science Review. 19 (3): 439-453. 
Auty, Richard M. 1993. Sustaining Development in Mineral Economies: The Resource Curse Thesis. London: Routledge

Bickel, Robert. 2007. Multilevel Analysis for Applied Research: It's Just Regression! New York: the Guilford Press.

Boix, Carles. 2003. Democracy and Redistribution. Cambridge: Cambridge University Press.

Collier,Paul and Nicholas Sambanis. Eds. 2005. Understanding Civil War. Washington DC: World Bank.

Dahlerup, Drude. Ed. 2006. Women, Quotas and Politics London: Routledge.

Dunning, Thad. 2008. Crude Democracy: Natural Resource Wealth and Political Regimes New York: Cambridge University Press.

Freedom House. 2009. Freedom in the World. www.freedomhouse.org

Gelman, Andrew and Jennifer Hill. 2007. Data Analysis Using Regression and Multilevel/Hierarchical Models. New York: Cambridge University Press.

Humphreys, M. 2005. 'Natural resources, conflict, and conflict resolution - Uncovering the mechanisms.' Journal of Conflict Resolution 49 (4): 508-537.

Inglehart, Ronald and Pippa Norris. 2003. Rising Tide: Gender Equality \& Cultural Change around the World. New York: Cambridge University Press.

International IDEA. 2008. The Arab Quota Report: Selected Case Studies. Stockholm: International IDEA.

Interparliamentary Union. 2009. Women in parliaments worldwide. www.ipu.org

Iversen, Torbin and Frances Rosenbluth. 2008. 'Work and power: The connection between female labor force participation and female political representation.' Annual Review of Political Science 11: 479.

Jensen, N. and L. Wantchekon. 2004. 'Resource wealth and political regimes in Africa.' Comparative Political Studies 37, 816-841.

Kang, Alice. 2009. 'Studying Oil, Islam, and Women as if Political Institutions Mattered.' Politics \& Gender. (Forthcoming)

Krook, Mona Lena. 2009. Quotas for Women in Politics: Gender and Candidate Selection Reform Worldwide Oxford: Oxford University Press. 
Meriwether, Margaret L. and Judith E. Tucker. Eds. 2000. Social history of women and gender in the modern Middle East. Boulder, Co: Westview Press.

Moaddel, Mansoor. (Ed). 2007. Values and Perceptions of the Islamic and Middle Eastern Publics. New York : Palgrave McMillan.

Moghadam, Valentine M. 1993. Modernizing women: gender and social change in the Middle East. Boulder, CO: Lynne Reinner.

Norris, Pippa and Ronald Inglehart. 2003. 'Muslims and the West: Testing the 'Clash of Civilizations' Thesis.' Comparative Sociology. 1 (3-4): 235-265.

Norris, Pippa and Ronald Inglehart. 2004. Sacred and Secular: Politics and Religion Worldwide. New York: Cambridge University Press.

Norris, Pippa and Joni Lovenduski. 1995. Political Recruitment: Gender, Race and Class in the British Parliament. Cambridge: Cambridge University Press.

Norris, Pippa. 2009. 'Petroleum Patriarchy.' Politics \& Gender (forthcoming)

Norris, Pippa. 2004. Electoral Engineering. New York: Cambridge University Press.

Norris, Pippa. 2007. 'Opening the door: Women leaders and constitution-building in Iraq and Afghanistan.' In Women Who Lead Ed. Barbara Kellerman. New York: Jossey Bass. Pp.197-226.

Omar, Samira A.S. 1995. 'Constraints That Hinder Women's Participation in Development: The Case of Kuwait.' Pakistan Journal of Women's Studies 2(2): 17-26.

Pettersson, Thorleif. 2007. 'Muslim immigrants in Western Europe: Persisting value differences or value adaptation?' In Mansoor Moaddel (ed) Values and Perceptions of the Islamic and Middle Eastern Publics. New York: Palgrave McMillan.

Raudenbush, Stephen W. and Anthony S. Bryk. 2002. Hierarchical Linear Models $\left(2^{\text {nd }}\right.$ ed). Thousand Oaks, CA: Sage

Rizzo, H., A.H. Abdel-Latif, and K. Meyer, 'The relationship between gender equality and democracy: A comparison of Arab versus non-Arab Muslim societies'. Sociology-the Journal of the British Sociological Association, 2007. 41(6): 1151-1170.

Ross, Michael L. 2001. 'Does oil hinder democracy?' World Politics 53: 325-361. 
Ross, Michael L. 2004. 'How do natural resources influence civil war? Evidence from thirteen cases.' International Organization 58 (1): 35-67.

Ross, Michael L. 2006. 'A closer look at oil, diamonds, and civil war.' Annual Review of Political Science. 9: 265-300.

Ross, Michael L. 2008. 'Oil, Islam and Women.' American Political Science Review 102(1):107-123.

Schlozman, Kay L. 1999. "'What happened at work today?" A multistage model of gender, employment, and political participation.' Journal Of Politics 61: 29.

Snyder, Richard. 2006. 'Does lootable wealth breed disorder? A political economy of extraction framework.' Comparative Political Studies 39 (8): 943-968.

Spierings, Niels, Jeroen Smits, and Mieke Verloo. 2009. 'On the Compatibility of Islam and Gender Equality: Effects of Modernization, State Islamization, and Democracy on Women's Labor Market Participation in 45 Muslim Countries.' Social Indicators Research 90 (3): 503-22.

Suad, Joseph and Susan Slyomovics. 2001. Women and power in the Middle East. Philadelphia: University of Pennsylvania Press.

UNDP. 2006. Arab Human Development Report: Towards the Rise of Women in the Arab World. United Nations Development Programme.

1 The exceptions to Arab state endorsement of CEDAW are Oman, Qatar, Somalia, Sudan and the Occupied Palestinian Territories.

${ }^{2}$ Full methodological details about the World Values Surveys, including the questionnaires, sampling procedures, fieldwork procedures, principle investigators, and organization can be found at: http://wvs.isr.umich.edu/wvs-samp.html.

${ }^{3}$ These regimes are classified according to the 2009 Freedom House assessments of political rights and civil liberties Freedom House. 2009. Freedom in the World. www.freedomhouse.org. 